\title{
Sensitivity of Mediterranean amphipods and sea urchins to reference toxicants
}

\section{Sensibilidad de anfípodos y erizos del Mar Mediterráneo a sustancias tóxicas de referencia}

\author{
A. Cesar ${ }^{1,2 *}$ \\ L. Marín-Guirao ${ }^{1}$ \\ R. Vita ${ }^{1}$ \\ A. Marín ${ }^{1}$ \\ ${ }^{1}$ Departamento de Ecología e Hidrología \\ Facultad de Biología \\ Universidad de Murcia \\ Murcia 30100, Spain \\ *E-mail: aucesar@um.es \\ ${ }^{2}$ Departamento de Ecotoxicología \\ Universidade Santa Cecilia \\ Rua Owaldo Cruz, n.266 \\ Santos, 11045-907, SP, Brazil \\ Recibido en febrero de 2002; aceptado en septiembre de 2002
}

\begin{abstract}
Toxicity tests were performed in two amphipod species, Gammarus aequicauda and Microdeutopus gryllotalpa, and three sea urchin species, Arbacia lixula, Paracentrotus lividus and Sphaerechinus granularis. The sensitivity of these marine organisms was evaluated by acute toxicity tests with amphipod juveniles and short chronic embryo-larval tests in sea urchins using the reference toxicants, ammonium chloride $\left(\mathrm{NH}_{4} \mathrm{Cl}\right)$, cadmium chloride $\left(\mathrm{CdCl}_{2}\right)$, potassium dichromate $\left(\mathrm{K}_{2} \mathrm{Cr}_{2} \mathrm{O}_{7}\right)$, sodium dodecylsulfate $\left(\mathrm{C}_{12} \mathrm{H}_{25} \mathrm{NaO}_{4} \mathrm{~S}\right)$ and zinc sulfate $\left(\mathrm{ZnSO}_{4}\right)$. The acute toxicity tests in amphipods clearly demonstrated the toxicity gradient of these substances. A two-way ANOVA analysis showed that M. gryllotalpa was more sensitive than G. aequicauda to all the reference toxicants studied $(P<0.0001)$. The tests conducted with sea urchins also pointed to a toxicant gradient and these organisms were seen to be more sensitive than amphipods. The two-way ANOVA analysis showed no significant differences in the IC25 and IC50 values for each reference toxicant in the three sea urchin species. The interaction of sea urchin species and a reference toxicant had no significant effect (two-way ANOVA, $P=0.9$ ), the sensitivity of these Mediterranean species and groups being similar to that of other amphipod and sea urchin species found in the bibliography. The objective of our study is to provide ecotoxicological tools to evaluate the potential toxicity of Mediterranean benthic ecosystems, and in this work, we characterize the toxicity of reference toxicants towards autochthonous species of amphipods and sea urchins.
\end{abstract}

Key words: Amphipods, sea urchins, toxicity, reference toxicants.

\section{Resumen}

Se evaluó la sensibilidad de dos especies de anfípodos, Gammarus aequicauda y Microdeutopus gryllotalpa, y tres especies de erizos de mar, Arbacia lixula, Paracentrotus lividus y Sphaerechinus granularis, por medio de tests de toxicidad aguda en anfípodos juveniles y tests crónicos de corta duración en erizos (embriolarval). Se emplearon como sustancias tóxicas de referencia: cloruro amónico $\left(\mathrm{NH}_{4} \mathrm{Cl}\right)$, cloruro de cadmio $\left(\mathrm{CdCl}_{2}\right)$, dicromato potásico $\left(\mathrm{K}_{2} \mathrm{Cr}_{2} \mathrm{O}_{7}\right)$, dodecilo sulfato de sodio $\left(\mathrm{C}_{12} \mathrm{H}_{25} \mathrm{NaO}_{4} \mathrm{~S}\right)$ y sulfato de zinc $\left(\mathrm{ZnSO}_{4}\right)$. El análisis ANOVA de dos vías mostró que $M$. gryllotalpa es más sensible que $G$. aequicauda a todas las sustancias tóxicas de referencia estudiadas $(P<0.0001)$. Tanto en el caso de los anfípodos como en el de los erizos de mar se estudió un gradiente de concentraciones para las sustancias tóxicas de referencia, presentando los erizos de mar, en todos los casos, una mayor sensibilidad que los anfípodos. La interacción entre las especies de erizos y las sustancias tóxicas de referencia no presentaron ningún efecto significativo (ANOVA de dos vías, $P=0.9$ ). La sensibilidad de estos grupos de organismos mediterráneos es similar a la de otras especies de anfípodos y erizos encontradas en la bibliografía. El objetivo de nuestro estudio es proporcionar herramientas ecotoxicológicas para la evaluación de la toxicidad potencial en los ecosistemas bentónicos mediterráneos, caracterizando la toxicidad de cinco sustancias tóxicas de referencia con relación a cinco especies autóctonas de anfípodos y erizos de mar.

Palabras clave: Anfípodos, erizos de mar, toxicidad, sustancias tóxicas de referencia. 


\section{Introduction}

In the aquatic environment, most anthropogenic chemicals and waste materials, including toxic organic and inorganic chemicals, eventually contribute to environmental degradation. The sensitivity of an organism is related to the exposure route (interstitial water, sediment particles or overlying water) and its biochemical response to pollutants. Toxicity tests have become effective tools, providing direct, quantifiable evidence of the biological consequences of contamination, and can be used to measure the interactive toxic effects of complex contaminant mixtures in water and at the sediment-water interface. An important consideration for developing test methods using specific species is to know the relative sensitivity of the organisms to both individual chemical and complex mixtures (U.S. EPA, 1994).

The experiments were performed with two juvenile amphipod species, Gammarus aequicauda (Martinov, 1931) and Microdeutopus gryllotalpa (A. Costa, 1853), and embryos of three sea urchin species, Arbacia lixula (Linnaeus, 1758), Paracentrotus lividus (Lamarck, 1816) and Sphaerechinus granularis (Lamarck, 1816), through embryo-larval toxicity tests. The life history characteristics of these marine organisms have been described in detail by several authors (Ruffo, 1982; Riedl, 1986; Martín et al., 1999). Exposure tests used the reference toxicants, ammonium chloride $\left(\mathrm{NH}_{4} \mathrm{Cl}\right)$, cadmium chloride $\left(\mathrm{CdCl}_{2}\right)$, potassium dichromate $\left(\mathrm{K}_{2} \mathrm{Cr}_{2} \mathrm{O}_{7}\right)$, sodium dodecyl-sulfate $\left(\mathrm{C}_{12} \mathrm{H}_{25} \mathrm{NaO}_{4} \mathrm{~S}\right)$ and zinc sulfate $\left(\mathrm{ZnSO}_{4}\right)$. Infaunal amphipods are excellent for short-term toxicity tests and are strongly recommended as appropriate test species for acute toxicity tests in marine waters and sediments (U.S. EPA, 1994; ASTM, 1997). Echinoderm embryo-larval development tests have been widely used to characterize a variety of toxicants, including liquid and solid phase protocols (Bryn et al., 1998; Hunt et al., 2001a, b). Many contaminants may affect the survival of larvae and adult sea urchins (Nacci et al., 1986). Generally, amphipods and echinoderms constitute an ideal tool for marine ecotoxicological tests (Gannon and Beeton, 1971; Swartz et al., 1982; Nipper et al., 1993; Carr, Long et al., 1996; DelValls et al., 1998; Cesar et al., 2000; Hunt et al., 2001a, b). For marine pollution studies, experiments involving sea urchin eggs and embryos are straightforward, rapid and extremely sensitive, providing results of great uniformity and accuracy. Sea urchins are the ideal candidates for this kind of study because they have been used extensively for several decades to study embryonic development (Lee, 1984). In general, such experiments have been accepted internationally as appropriate for toxicity tests (U.S. EPA, 1995; Environment Canada, 1992; CETESB, 1999). The suitability of test organisms collected in the field or cultured must be verified by conducting a reference toxicity test. The United States Environmental Protection Agency and the American Society for Testing and Materials have developed testing methods for species of equinoids and amphipods indigenous to their Atlantic and Pacific coasts (U.S. EPA, 1988 and ASTM, 1990). In contrast, there are no standard

\section{Introducción}

En el ambiente acuático la mayor parte de las sustancias químicas antropogénicas y materiales de desecho, incluyendo sustancias tóxicas orgánicas e inorgánicas, eventualmente contribuyen a la degradación medioambiental. La sensibilidad de un organismo está relacionada con la ruta de exposición (agua intersticial, partículas del sedimento o agua sobrenadante) y con su respuesta bioquímica frente a los contaminantes. Los tests de toxicidad se han convertido en una importante herramienta de control ambiental, proporcionando una evidencia directa y cuantificable de las consecuencias de la contaminación, y pudiendo ser usados para medir la toxicidad de mezclas complejas de contaminantes tanto en el agua como en la interfase sedimento-agua. Una consideración importante para desarrollar estos métodos de experimentación usando especies específicas es saber la sensibilidad relativa de los organismos tanto para sustancias químicas individuales como para mezclas complejas (U.S. EPA, 1994).

Se realizaron ensayos con juveniles de dos especies de anfípodos, Gammarus aequicauda (Martinov, 1931) y Microdeutopus gryllotalpa (A. Costa, 1853), y embriones de tres especies de erizos de mar, Arbacia lixula (Linnaeus, 1758), Paracentrotus lividus (Lamarck, 1816) y Sphaerechinus granularis (Lamarck, 1816). Las características distintivas y ecológicas de estos organismos están descritas detalladamente en la bibliografía por diversos autores (Ruffo, 1982; Riedl, 1986; Martín et al., 1999). La sensibilidad de estos organismos marinos fue evaluada mediante tests de toxicidad aguda con juveniles de anfípodos y tests embriolarvales crónicos de corta duración con los erizos, usando las siguientes sustancias tóxicas de referencia: cloruro amónico $\left(\mathrm{NH}_{4} \mathrm{Cl}\right)$, cloruro de cadmio $\left(\mathrm{CdCl}_{2}\right)$, dicromato potásico $\left(\mathrm{K}_{2} \mathrm{Cr}_{2} \mathrm{O}_{7}\right)$, dodecilo sulfato de sodio $\left(\mathrm{C}_{12} \mathrm{H}_{25} \mathrm{NaO}_{4} \mathrm{~S}\right)$ y sulfato de zinc $(\mathrm{ZnSO} 4)$. Los anfípodos, representantes de la infauna, son excelentes para su utilización en tests de toxicidad agudos o crónicos y son normalmente recomendados como organismos tests en la evaluación de la toxicidad en aguas y sedimentos marinos (U.S. EPA, 1994; ASTM, 1997). Los experimentos de fecundación y de desarrollo embriolarval con equinodermos han sido ampliamente utilizados en la caracterización de una gran variedad de sustancias tóxicas y actualmente están incluidos en los protocolos para la determinación de contaminantes en la interfase sedimento-agua (Bryn, 1998; Hunt et al., 2001a,b). Un gran número de contaminantes pueden afectar a los erizos de mar, especialmente en el desarrollo larvario, y a los adultos (Nacci et al., 1986). Habitualmente, los tests de toxicidad con anfípodos y equinodermos constituyen una herramienta ideal para los estudios ecotoxicológicos (Gannon y Beeton, 1971; Swartz et al., 1982; Nipper et al., 1993; Carr, Long et al., 1996; DelValls et al., 1998; Cesar et al., 2000; Hunt et al., 2001a, b). En estudios de contaminación marina, los experimentos relacionados con los efectos de los contaminantes en la fecundación y embriogenia de los erizos de mar son elegidos por su facilidad 
protocols for conducting toxicity tests with the native amphipod and sea urchin species of the Mediterranean coasts.

The objective of our study was to provide ecotoxicological tools for evaluating the potential toxicity of Mediterranean ecosystems. In this work we characterize the toxicity of five reference toxicants towards two amphipod and three sea urchin autochthonous species.

\section{Materials and methods}

\section{Collection, holding and acclimation of test organisms}

Amphipods were collected from saline coastal lagoons in the Santa Pola and San Pedro natural reserves, SE Spain, using a $0.5-\mathrm{mm}$ sieve and storing them in polyethylene buckets containing algal species, water and sediment from the collection site. Large predators were discarded. The amphipods were immediately transported in constant-temperature containers to the laboratory, where they were maintained in glass aquaria with filtered natural seawater $\left(0.45-\mu \mathrm{m} / \mathrm{GFC}\right.$ Whatman $\left.{ }^{\circledR}\right)$, under constant aeration. Their food supply consisted on Purina ${ }^{\circledR}$ Rabbit Chow and Tetra-Min ${ }^{\circledR}$ fish food (mixed 1:1). The amphipods were gradually acclimated to the test conditions for $72 \mathrm{~h}$ and then randomly selected for testing.

The sea urchins were obtained by scuba divers off the Fraile, Aguilas and Farallón islands, Cabo de Palos (Murcia, Spain), and were immediately transported to the laboratory in constant-temperature containers covered with macroalgae. In the laboratory, the sea urchins were kept in glass aquaria with filtered natural seawater, which was constantly renewed (approximately $50 \mathrm{~L} \mathrm{~min}^{-1}$ ). They received a daily algal food supply collected at the same sampling sites during the acclimation period. At the end of the experiments the sea urchins were returned back to the sea.

\section{Amphipod toxicity tests}

The water-only reference toxicant tests of the amphipods Gammarus aequicauda and Microdeutopus gryllotalpa were carried out using three reference toxicants, ammonium chloride $\left(\mathrm{NH}_{4} \mathrm{Cl}\right)$, potassium dichromate $\left(\mathrm{K}_{2} \mathrm{Cr}_{2} \mathrm{O}_{7}\right)$ and sodium dodecyl-sulfate $\left(\mathrm{C}_{12} \mathrm{H}_{25} \mathrm{NaSO}_{4}\right)$, in accordance with the protocols of ASTM (1997) and U.S. EPA (1994) slightly adapted. The results of a preliminary test were used to set the definitive concentrations of each substance. The control water and dilution water used in the experiments consisted of natural seawater (38 psu) collected in unpolluted areas (from where the sea urchins were also collected) and filtered through a GFC Whatman ${ }^{\circledR}(0.45-\mu \mathrm{m})$ filter. Six different concentrations and one seawater control were used for each test. Four replicates were prepared per concentration of reference toxicant, using 1-L polyethylene vessels containing $400 \mathrm{~mL}$ of solution, and ten organisms (2 to $5 \mathrm{~mm}$ in length) were selected for each replicate test chamber. Amphipods were excluded if they were gravid females or in noticeably poor health. Tests were maintained at constant conditions of $20^{\circ} \mathrm{C}$ and 1000 lux 16:8-h de aplicación, rapidez y principalmente por la sensibilidad que estos organismos presentan, generando resultados de gran uniformidad y precisión. Los erizos de mar han sido empleados ampliamente durante varias décadas en estudios de desarrollo embrionario (Lee, 1984), lo que actualmente fundamenta su utilización en tests de toxicidad. En general, estos dos grupos de organismos son aceptados internacionalmente para su utilización en tests de toxicidad (U.S. EPA, 1995; Environment Canadá, 1992; CETESB, 1999). La idoneidad de los organismos tests obtenidos en campo o mediante cultivo debe de ser evaluada a través de tests de toxicidad con sustancias de referencia. La Agencia de Protección Medioambiental de los Estados Unidos y la Sociedad Americana para la Experimentación y Materiales han desarrollado métodos de test para especies de equinodermos y anfípodos típicos de la costa atlántica y pacífica americana (U.S. EPA, 1988 y ASTM, 1990). En cambio, no existen protocolos estandarizados para llevar a cabo experimentos de toxicidad con especies nativas de anfípodos y erizos del Mar Mediterráneo.

El objetivo de este estudio es proporcionar una base metodológica para el establecimiento de herramientas ecotoxicológicas en la evaluación de la toxicidad de los ecosistemas costeros mediterráneos. En este trabajo se ha determinado la sensibilidad de dos especies autóctonas de anfípodos y tres de erizos de mar frente a cinco sustancias tóxicas diferentes, normalmente utilizadas internacionalmente.

\section{Materiales y métodos}

Recolección, manejo y aclimatación de los organismos tests

Los anfípodos fueron recolectados en lagunas costeras de las reservas naturales de Santa Pola y de San Pedro, SE de España, utilizando un tamiz de $0.5 \mathrm{~mm}$ de luz, y posteriormente fueron transferidos a contenedores de polietileno con agua, sedimentos y recubiertos con macroalgas del lugar de colecta, tomándose el cuidado de descartar sus posibles depredadores. Los organismos fueron inmediatamente transportados al laboratorio manteniendo su temperatura constante. En el laboratorio se mantuvieron en un acuario con agua de mar natural filtrada $\left(0.45 \mu \mathrm{m} / \mathrm{GFC}\right.$ Whatman $\left.{ }^{\circledR}\right)$ bajo condiciones constantes de temperatura y aireación. Los organismos fueron alimentados diariamente con una mezcla $(1: 1)$ de pienso de conejo (Purina $\AA$ ) y de pescado (Tetra-Min $\AA$ ). Los anfípodos fueron gradualmente aclimatados a las condiciones del experimento durante $72 \mathrm{~h}$ y posteriormente seleccionados al azar para los ensayos.

Los erizos de mar fueron recolectados por buceadores con escafandra autónoma en las Islas del Fraile, Águilas y en la del Farallón, Cabo de Palos (Murcia, España), cubiertos con macroalgas del sitio de colecta e inmediatamente transportados al laboratorio en recipientes a temperatura constante. En el laboratorio, los erizos eran mantenidos en acuarios con agua de mar natural filtrada, constantemente renovada 
light:dark photoperiod, in a culture chamber (ASL-Snijders). All static acute tests lasted $48 \mathrm{~h}$, without adding any food. The number of survivors in each chamber was examined at the end of the exposure period.

At the beginning and the end of every test, the overlying water quality parameters including temperature, salinity, dissolved oxygen and $\mathrm{pH}$ were measured to ensure the acceptability of the tests, following standard methods (APHA, 1995; Buchanan, 1984).

\section{Sea urchin embryo-larval toxicity test}

Short-term chronic toxicity tests were developed with four reference toxicants, ammonium chloride $\left(\mathrm{NH}_{4} \mathrm{Cl}\right)$, cadmium chloride $\left(\mathrm{CdCl}_{2}\right)$, sodium dodecyl-sulfate $\left(\mathrm{C}_{12} \mathrm{H}_{25} \mathrm{NaSO}_{4}\right)$ and zinc sulfate $\left(\mathrm{ZnSO}_{4}\right)$, in accordance with slightly adapted guidelines (U.S. EPA, 1995; Environment Canada, 1997 and CETESB, 1999). The sea urchin embryo-larval toxicity tests were conducted with the three echinoid species Arbacia lixula, Paracentrotus lividus and Sphaerechinus granularis. Adult female and male urchins were stimulated to spawn with a mild electric shock $(35 \mathrm{~V})$ and the gametes were collected separately. Eggs were collected in $200-\mathrm{mL}$ beakers containing dilution seawater, and sperm was collected directly from the sea urchin gonopore with a micropipette and held on ice until egg fertilization. The organisms were allowed to spawn for up to 10 min, during which time careful observations were made of the amount of gametes released, their color and the overall behavior of the spawners. Animals that provided relatively little or dilute gametes were excluded from testing. Each batch of eggs was observed under a microscope in a Sedgwick-Rafter cell; eggs with abnormalities were discarded. The selected egg batches were then filtered through a $100-\mu \mathrm{m}$ screen to remove pellets, and pooled in a beaker containing $400-\mathrm{mL}$ dilution seawater. Eggs were washed three times by decantation, removing the supernatant and adding dilution seawater. Gametes obtained from at least two or three organisms of each sex were combined and their densities determined. A standard sperm solution was prepared by adding $0.5 \mathrm{~mL}$ of sperm to $24.5 \mathrm{~mL}$ of dilution seawater. At the beginning of the study, pretrial testing was conducted in order to determine the fecundation ratio and only rates higher than $90 \%$ were employed. The volume of solution added to the test tubes for each experiment was calculated according to the desired number of organisms required, approximately 400 fertilized eggs being added to each test chamber. This volume did not exceed $100 \mu \mathrm{L}$. The control water and dilution water used in the experiments was natural seawater ( $38 \mathrm{psu}$ ) collected in unpolluted areas (from where the sea urchins were also collected) and filtered through a GFC Whatman ${ }^{\circledR}$ filter. Six concentrations and ten seawater controls were used for each test. Three replicates were prepared per concentration, using $15-\mathrm{mL}$ polyethylene sterilized centrifuge tubes containing $10-\mathrm{mL}$ solution to which 400 embryos were added. All short-term chronic tests lasted 28 to $38 \mathrm{~h}$, according to the species, and the number of normally developed embryos (aproximadamente $50 \mathrm{~L} \mathrm{~min}^{-1}$ ). Durante el período de aclimatación los erizos fueron alimentados una vez al día a partir de algas congeladas recogidas en el mismo lugar donde fueron recolectados. Al final de los experimentos los erizos adultos eran devueltos al mar.

\section{Test de toxicidad con anfípodos}

Los experimentos de sensibilidad de fase líquida con los anfípodos, Gammarus aequicauda y Microdeutopus gryllotalpa, fueron realizados con las sustancias tóxicas de referencia, cloruro amónico $\left(\mathrm{NH}_{4} \mathrm{Cl}\right)$, dicromato potásico $\left(\mathrm{K}_{2} \mathrm{Cr}_{2} \mathrm{O}_{7}\right)$ y dodecilo sulfato de sodio $\left(\mathrm{C}_{12} \mathrm{H}_{25} \mathrm{NaO}_{4} \mathrm{~S}\right)$, de acuerdo con los estándares (ASTM 1997 y U.S. EPA 1994), inlcuyendo pequeñas adaptaciones para nuestras condiciones. Los resultados de los tests preliminares eran utilizados para determinar las concentraciones definitivas de cada sustancia. El agua de control y de dilución utilizada en los experimentos fue recogida en zonas no impactadas, con salinidad en torno a 38 psu y filtrada a través de un filtro de $0.45 \mu \mathrm{m}(\mathrm{GFC} /$ Whatman $\left.{ }^{\circledR}\right)$ antes de su utilización. Para cada test se emplearon seis concentraciones diferentes y una de control, con tres réplicas por concentración para cada sustancia tóxica de referencia, usando recipientes de polietileno de $1 \mathrm{~L}$, conteniendo $400 \mathrm{~mL}$ de solución y 10 organismos (de 2 a $5 \mathrm{~mm}$ de longitud) para cada réplica. Las hembras ovígeras y los organismos con evidente debilidad eran excluidos. Los tests se mantuvieron en una cámara de cultivo (ASL-Snijders), con temperatura $\left(20^{\circ} \mathrm{C}\right)$ e iluminación (1000 lux) constantes, con un fotoperíodo de 16:8h, luz:oscuridad. Los experimentos agudos con anfípodos tuvieron una duración de $48 \mathrm{~h}$, sin adición de alimento. El número de supervivientes en cada réplica fue examinado al final del período de exposición.

\section{Test de toxicidad embriolarval con erizos de mar}

Los tests de toxicidad crónica de corta duración fueron desarrollados con cuatro sustancias tóxicas de referencia, cloruro amónico $\left(\mathrm{NH}_{4} \mathrm{Cl}\right)$, cloruro de cadmio $\left(\mathrm{CdCl}_{2}\right)$, dodecilo sulfato de sodio $\left(\mathrm{C}_{12} \mathrm{H}_{25} \mathrm{NaO}_{4} \mathrm{~S}\right)$ y sulfato de zinc $(\mathrm{ZnSO} 4)$, de acuerdo con los protocolos (U.S. EPA, 1995; Environment Canadá, 1997 y CETESB, 1999), con pequeñas modificaciones para nuestras condiciones. Los tests de toxicidad embriolarval fueron realizados con tres especies de equinodermos, Arbacia lixula, Paracentrotus lividus y Sphaerechinus granularis. Los erizos adultos (hembras y machos) fueron estimulados para la liberación de los gametos mediante descargas eléctricas ( $35 \mathrm{~V}$ ) y los gametos recogidos de manera separada. Los huevos fueron recolectados en vasos de precipitado con agua de mar $(200 \mathrm{~mL})$ y los espermatozoides fueron recogidos en seco directamente del gonoporo con el auxilio de una micropipeta, depositados en un vaso de precipitado $(30 \mathrm{~mL})$ y conservados en hielo hasta el momento de la fertilización. Se recolectaron 
was counted at the end of the test. Tests were carried out at $20^{\circ} \mathrm{C}$, with a 1000 -lux 16 -h light:8-h dark photoperiod in a culture chamber (ASL-Snijders). The exposure period varied from $28 \mathrm{~h}$ for $P$. lividus to $38 \mathrm{~h}$ for A. lixula and S. granularis. Tests finished when at least $90 \%$ of the control embryos reached the normal pluteus larvae stage (evidenced by the formation of a three-part gut and the skeletal rods), at which point each test tube was fixed with $10 \%$ buffered formalin to preserve the samples. They were then examined microscopically in a Sedgewick-Rafter cell to determine the percentage that developed, calculating the normal/abnormal ratio for the first 100 embryos found in each tube. The results of a preliminary test were used to set the definitive concentrations of each substance.

At the beginning and at the end of every test, the overlying water quality parameters, including temperature, salinity, dissolved oxygen and $\mathrm{pH}$ content, were measured to ensure the acceptability of the tests, following standard methods (APHA, 1995; Buchanan, 1984).

\section{Data analysis}

As an estimate of the effective toxic concentration of amphipods, 48-h EC50 values and their respective 95\% confidence limits were calculated for all substances using the Trimmed Spearman-Karber method (Hamilton et al., 1977). Differences in EC50 and between amphipod species and reference toxicants were evaluated by two-way ANOVA. The inhibiting concentration (IC) for a specified effect (IC25 and IC50) on sea urchins was calculated using the Linear Interpolation Method (U.S. EPA, 1993). Two-way ANOVA analyses were used to evaluate significant differences in IC25 and IC50 among sea urchin species for each reference toxicant. The precision of the laboratory data was calculated for all species from the variation coefficient (CV\%), using the mean and relative standard deviation with the following equation:

$$
\mathrm{CV} \%=\frac{\text { standard deviation }}{\text { mean }} \times 100
$$

\section{Results}

\section{Amphipod toxicity tests}

The reference toxicants adversely affected both species to a similar extent (fig. 1), with higher survival rates being recorded in the control (greater than 80\%). The two-way ANOVA analysis showed that $M$. gryllotalpa was more sensitive than G. aequicauda to all the reference toxicants studied $(P<0.0001)$. There were significant differences in the effective concentration (EC50) values for ammonium chloride, potassium dichromate and sodium dodecyl-sulfate $(P=0.02)$. No significant differences were found in the amphipod speciesreference toxicant interaction $(P=0.2)$.

The effective concentrations (EC50, 48h) for $G$. los gametos liberados durante los primeros $10 \mathrm{~min}$ tras la inducción artificial, tiempo durante el cual se seleccionaron los lotes de óvulos según la cantidad liberada, el color y la forma general de los gametos. Los animales inmaduros que liberaban pocos gametos o se encontraban descoloridos o malformados fueron excluidos del experimento. Cada lote de huevos era observado al microscopio con el auxilio de una cámara de recuento (Sedgwick-Rafter); los lotes que mostraban alguna anormalidad eran excluidos. Los lotes seleccionados fueron filtrados a través de un tamiz de $100 \mu \mathrm{m}$ para retirar pelets y posteriormente fueron diluidos en un recipiente de $400 \mathrm{~mL}$ con agua de mar filtrada. Los huevos se lavaron tres veces por decantación, renovando el sobrenadante y diluyéndolos en agua. Paralelamente, una solución estándar de esperma se preparó añadiendo $0.5 \mathrm{~mL}$ de espermatozoides a $24.5 \mathrm{~mL}$ de una dilución de agua de mar filtrada. Antes de empezar los experimentos, se determinó el porcentaje de fecundación y sólo se utilizaron tasas superiores al $90 \%$. En cada réplica se añadieron aproximadamente 400 huevos fertilizados. El volumen de la solución conteniendo embriones añadida a los tubos de ensayo se calculó según el número de organismos requeridos. Este volumen no excedió los $100 \mu \mathrm{L}$. El agua control y el agua de dilución usada en los experimentos era agua natural de mar (38 psu) recogida en áreas no contaminadas (de donde los erizos de mar fueron recolectados) y filtrada a través de un filtro de $0.45 \mu \mathrm{m}\left(\mathrm{GFC} /\right.$ Whatman $\left.{ }^{\circledR}\right)$. En cada experimento fueron utilizados diez controles de agua de mar y seis concentraciones, con tres réplicas para cada concentración. Se emplearon tubos de centrífuga de poliestireno esterilizados de $15 \mathrm{~mL}$, a los que se añadían $10 \mathrm{~mL}$ de solución y 400 embriones por réplica. Los experimentos crónicos de corta duración tuvieron un período de exposición que varió desde $28 \mathrm{~h}$, para P. lividus, hasta $38 \mathrm{~h}$ para A. lixula y $S$. granularis, anotando el número de embriones normalmente desarrollados al final del test. Los experimentos se realizaron a $20^{\circ} \mathrm{C}$, con un fotoperíodo $16: 8 \mathrm{~h}$, luz:oscuridad (1000 lux) en una cámara de cultivo (ASLSnijders). Los tests se daban por concluidos cuando, en el control, al menos el $90 \%$ de los embriones alcanzaron el estadio típico, denominado larva plúteos, evidenciado por la formación del tubo digestivo y la constitución de los tres apéndices esqueléticos iniciales. En esta etapa, cada réplica se fijó con formaldehído tamponado con bórax para conservar la estructura de las larvas hasta el momento de la lectura. Para la lectura de los datos, las larvas fueron examinadas al microscopio a través de la cámara de recuento (Sedgewick-Rafter), y se determinó el porcentaje de desarrollo normal/anormal para los primeros 100 embriones tomados en cada tubo de ensayo. Las concentraciones definitivas de cada sustancia de referencia también fueron establecidas de acuerdo con los resultados obtenidos en los experimentos preliminares. Al comienzo y al final de cada test, los parámetros de calidad del agua sobrenadante incluyendo temperatura, salinidad, oxígeno disuelto y $\mathrm{pH}$ fueron medidos para asegurar la aceptabilidad de los experimentos, siguiendo métodos estandarizados (APHA, 1995; Buchanan, 1984). 
aequicauda and for M. gryllotalpa, together with the standard deviations (s.d.), the number of experiments and the variation coefficient are described below and in figure 1 . The results for G. aequicauda were $49.68 \pm$ s.d. $11.24 \mathrm{mg} \mathrm{L}^{-1}$ in the case of ammonium chloride $(n=4), \mathrm{CV} \%=22.62 ; 9.52 \pm$ s.d. $4.7 \mathrm{mg}$ $\mathrm{L}^{-1}$ for potassium dichromate $(n=5), \mathrm{CV} \%=49.36$; and $5.46 \pm$ s.d. $0.73 \mathrm{mg} \mathrm{L}^{-1}$ for sodium dodecyl-sulfate $(n=4), \mathrm{CV} \%=$ 13.36. The effective concentrations for M. gryllotalpa were lower: $35.54 \pm$ s.d. $8.0 \mathrm{mg} \mathrm{L}^{-1}$ for ammonium chloride $(n=3)$, $\mathrm{CV} \%=22.50 ; 6.0 \pm$ s.d. $0.6 \mathrm{mg} \mathrm{L}^{-1}$ for potassium dichromate $(n=3), \mathrm{CV} \%=10.56$ and $2.98 \pm$ s.d. $0.49 \mathrm{mg} \mathrm{L}^{-1}$ for sodium dodecyl-sulfate $(n=6), C V \%=16.44$. The sensitivity of these Mediterranean species was similar to that of other amphipod species described in the bibliography (ASTM, 1997; Andrew, 1999; U.S. EPA, 1994). The variation coefficient for the amphipod toxicity tests using the reference toxicants pointed to an acceptable degree of precision. Water quality data $\left(\mathrm{T}^{\circ} \mathrm{C}\right.$, D.O., salinity and $\mathrm{pH}$ ) were constant and within acceptable limits during the experiments.

Sea urchin embryo-larval toxicity test

The sensitivity of embryo-larval sea urchin tests was similar for all three species, Arbacia lixula, Paracentrotus lividus and Sphaerechinus granularis. The two-way ANOVA analysis showed no significant differences in the IC25 and IC50 values for each reference toxicant in the three sea urchin species. The interaction of sea urchin species and reference toxicants had no significant effect (two-way ANOVA, $P=0.9$ ). The two-way ANOVA analysis of the IC50 of sea urchins demonstrated highly significant differences between reference toxicants $(P<0.00001)$. However, there were no significant differences

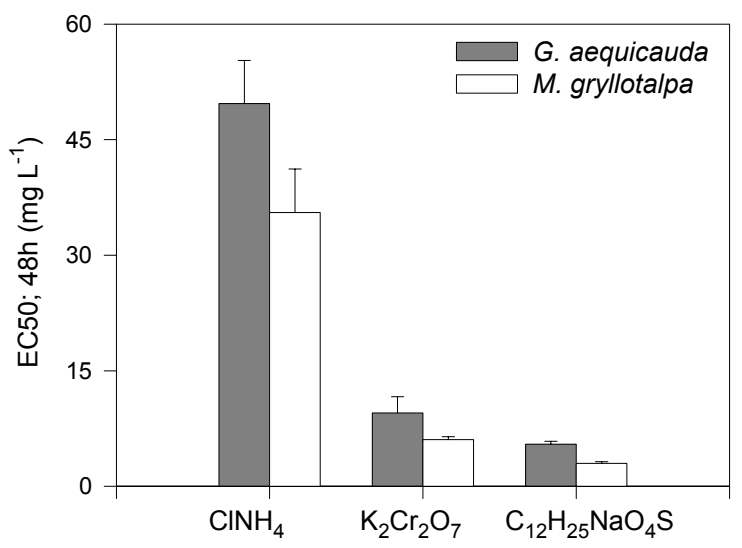

Figure 1. Sensitivity test results (EC50 \pm standard deviation) with the amphipods Gammarus aequicauda and Microdeutopus gryllotalpa for the reference toxicants, ammonium chloride $\left(\mathrm{NH}_{4} \mathrm{Cl}\right)$, potassium dichromate $\left(\mathrm{K}_{2} \mathrm{Cr}_{2} \mathrm{O}_{7}\right)$ and sodium dodecyl sulfate $\left(\mathrm{C}_{12} \mathrm{H}_{25} \mathrm{NaSO}_{4}\right)$.

Figura 1. Resultados de los tests de sensibilidad (EC50 \pm desviación estándar) con los anfípodos Gammarus aequicauda y Microdeutopus gryllotalpa para las sustancias toxicas de referencia, cloruro de amonio $\left(\mathrm{NH}_{4} \mathrm{Cl}\right)$, dicromato de potasio $\left(\mathrm{K}_{2} \mathrm{Cr}_{2} \mathrm{O}_{7}\right)$ y dodecilo sulfato de sodio $\left(\mathrm{C}_{12} \mathrm{H}_{25} \mathrm{NaSO}_{4}\right)$.
Análisis de los datos

La concentración tóxica efectiva para los anfípodos, CE50 48-h y sus respectivos límites de confianza del 95\%, fueron calculados para todas las sustancias usando el método Trimmed Spearman-Karber (Hamilton et al., 1977). Las diferencias entre las concentraciones efectivas (CE50) de las especies de anfípodos, para cada sustancia tóxica de referencia, fueron analizadas por medio de un ANOVA de dos vías. Las concentraciones de inhibición (IC25 e IC50) para cada especie de erizo de mar frente a las distintas sustancias tóxicas de referencia fueron calculadas a través del Método de Interpolación Lineal (U.S. EPA, 1993). Los análisis ANOVA de dos vías fueron utilizados para evaluar diferencias significativas entre los datos de IC25 e IC50) de las distintas especies de erizos con relación a cada sustancia tóxica de referencia. La precisión de los datos obtenidos en los experimentos de laboratorio se calculó a través del coeficiente de variación ( $\mathrm{CV} \%)$, donde se aplicó la media y la desviación estándar de acuerdo con la siguiente ecuación (U.S. EPA, 1995):

$$
\mathrm{CV} \%=\frac{\text { standard deviation }}{\text { mean }} \times 100
$$

\section{Resultados}

Tests de toxicidad con anfípodos

Las sustancias tóxicas de referencia causaron efectos adversos similares para ambas especies, comparándose con los efectos obtenidos en el control que siempre presentó tasas de supervivencia superiores al $80 \%$. El análisis ANOVA de dos vías demostró que $M$. gryllotalpa fue más sensible que $G$. aequicauda para todas las sustancias tóxicas de referencia estudiadas $(P<0.0001)$. Se encontraron diferencias significativas entre los valores de la concentración efectiva (CE50) para las sustancias de referencia, cloruro de amonio, dicromato potásico y dodecill sulfato de sodio $(P=0.02)$. No se encontraron diferencias significativas entre las especies de anfípodos en interacción con las sustancias tóxicas de referencia $(P=0.2)$.

Las concentraciones efectivas (CE, 48h) para $G$. aequicauda y para $M$. gryllotalpa, junto con las desviaciones estándar, el número de experimentos y los coeficientes de variación, se exponen a continuación y en la figura 1. Los resultados para $G$. aequicauda fueron $49.68 \pm$ d.e. $11.24 \mathrm{mg}$ $\mathrm{L}^{-1}$, en el caso del cloruro de amonio $(n=4 ; \mathrm{CV} \%=22.62)$, $9.52 \pm$ d.e $4.7 \mathrm{mg} \mathrm{L}^{-1}$, en el del dicromato potásico $(n=5$; $\mathrm{CV} \%=49.36)$, y $5.46 \pm$ d.e. $0.73 \mathrm{mg} \mathrm{L}^{-1}$, para el dodecilo sulfato de sodio $(n=4 ; \mathrm{CV} \%=13.36)$. Para $M$. gryllotalpa fueron de $35.54 \pm$ d.e. $8.0 \mathrm{mg} \mathrm{L}^{-1}$, para el cloruro de amonio $(n=3$; $\mathrm{CV} \%=22.50), 6.06 \pm$ d.e. 0.64, para el dicromato potásico $(n=3 ; \mathrm{CV} \%=10,56)$, y $2.98 \pm$ d.e. 0.49 para el dodecilo sulfato de sodio $(n=6 ; \mathrm{CV} \%=16.44)$. La sensibilidad de estas 
between the individual IC25 and IC50 values for the three species for each reference toxicant $(P>0.05)$. Neither the ANOVA analysis showed any significant toxicant-species interactions $(P>0.05)$.

The $25 \%$ and $50 \%$ inhibiting concentrations (IC25/IC50 \pm s.d. and $\mathrm{CV} \%$, respectively) for $A$. lixula were $1.71 / 2.48 \pm$ $0.07 / 0.04 \mathrm{mg} \mathrm{L}^{-1}$ in the case of ammonium chloride $(n=4)$, $\mathrm{CV} \%=4.09 / 1.6 ; 1.07 / 1.80 \pm 0.11 / 0.06 \mathrm{mg} \mathrm{L}^{-1}$ for cadmium chloride $(n=5), \mathrm{CV} \%=10.28 / 3.33 ; 1.10 / 1.56 \pm 0.04 / 0.06 \mathrm{mg}$ $\mathrm{L}^{-1}$ for sodium dodecyl-sulfate $(n=6), \mathrm{CV} \%=3,63 / 3,84$; and $0.03 / 0.05 \pm 0.001 / 0.002$ for zinc sulfate $(n=6), \mathrm{CV} \%=6.66 / 2$ (figs. 2, 3, 4, 5). For $P$. lividus they were 1.95/2,71 $\pm 0.17 / 1.19$ $\mathrm{mg} \mathrm{L}^{-1}$ in the case of ammonium chloride $(n=4), \mathrm{CV} \%=8.71 /$ 7.01; 1.18/2.06 $\pm 0.06 / 0.14 \mathrm{mg} \mathrm{L}^{-1}$ for cadmium chloride $(n=3), \mathrm{CV} \%=5.08 / 6.79 ; 1.01 / 1.49 \pm 0.04 / 0.04 \mathrm{mg} \mathrm{L}^{-1}$ for sodium dodecyl-sulfate $(n=6), \mathrm{CV} \%=3.96 / 2.68$ and; $0.03 /$ $0.05 \pm 0.001 / 0.001$ for zinc sulfate $(n=6), \mathrm{CV} \%=3.33 / 2$ (figs. $2,3,4,5)$. For $S$. granularis the inhibiting concentrations were $1.87 / 2.24 \pm 0.06 / 0.04 \mathrm{mg} \mathrm{L}^{-1}$ in the case of ammonium chloride $(n=4), \mathrm{CV} \%=3.20 / 1.78 ; 1.87 / 2.24 \pm 0.06 / 0.04 \mathrm{mg} \mathrm{L}^{-1}$ for cadmium chloride $(n=3), \mathrm{CV} \%=3.21 / 1.78 ; 1.06 / 1.65 \pm$ $0.06 / 0.04 \mathrm{mg} \mathrm{L}^{-1}$ for sodium dodecyl-sulfate $(n=5), \mathrm{CV} \%=$ $5.66 / 2.42$; and $0.03 / 0.06 \pm 0.001 / 0.001$ for zinc sulfate $(n=5)$, $\mathrm{CV} \%=3.33 / 2$ (figs. 2, 3, 4, 5). Zinc sulfate was slightly more toxic than the other four chemicals. The larval responses to dodecyl-sulfate were very uniform in the three sea urchin species, with a low standard deviation, the sensitivity of these Mediterranean species being similar to that of other species of sea urchins found in the bibliography (Kobayashi, 1980; 1984; Nacci, 1986). The variation coefficients for the sea urchin toxicity tests, based on IC25 and IC50, showed a good degree of precision. Water quality data $\left(\mathrm{T}^{\circ} \mathrm{C}\right.$, D.O., salinity and $\left.\mathrm{pH}\right)$ were constant and within acceptable limits during the experiments.

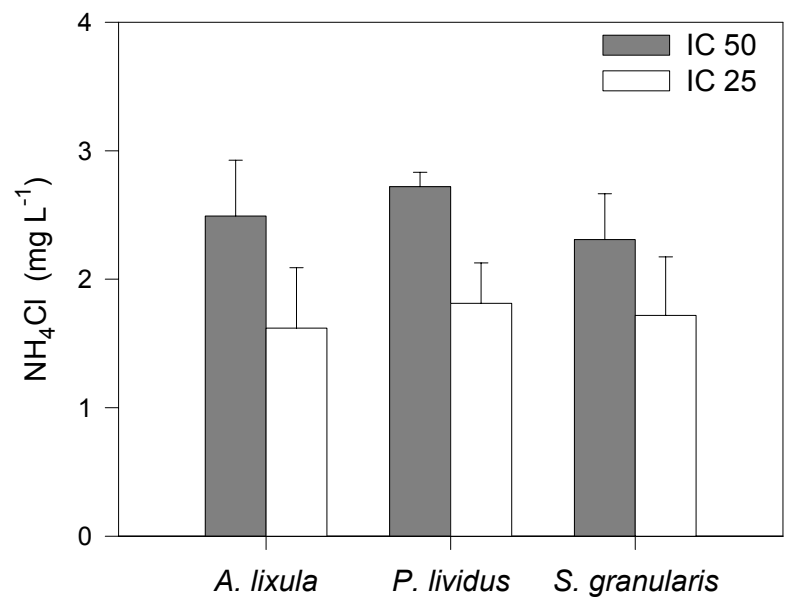

Figure 2. Reference toxicant results (IC25/50 \pm standard deviation) for ammonium chloride $\left(\mathrm{NH}_{4} \mathrm{Cl}\right)$ with sea urchins Arbacia lixula, Paracentrotus lividus and Sphaerechinus granularis.

Figura 2. Resultados de los tests de sensibilidad (IC25/50 \pm desviación estándar) con los erizos de mar Arbacia lixula, Paracentrotus lividus y Sphaerechinus granularis frente al cloruro de amonio $\left(\mathrm{NH}_{4} \mathrm{Cl}\right)$ como sustancia tóxica de referencia. especies mediterráneas se mostró similar a otras especies de anfípodos encontradas en la bibliografía (ASTM, 1997; Andrew, 1999; U.S.EPA, 1994). El coeficiente de variación (CV\%), entre los resultados obtenidos para las dos especies de anfípodos con relación a las tres sustancias tóxicas de referencia presentó una precisión aceptable. Los parámetros de calidad del agua (temperatura, oxígeno disuelto, salinidad y $\mathrm{pH})$ se mantuvieron constantes durante los experimentos, dentro de límites aceptables.

Test de toxicidad embriolarval con erizos de mar

Los experimentos de sensibilidad embriolarval con los erizos de mar exhibieron resultados similares para las tres especies, A. lixula, P. lividus y S. granularis. El análisis ANOVA de dos vías no demostró diferencias significativas en los valores IC25 e IC50 para las tres especies de erizos de mar ante cada sustancia tóxica de referencia. La interacción de las especies de erizos y las sustancias tóxicas de referencia no presentaron efectos significativos (ANOVA de dos vías, $P=0.9$ ). Comprobando la toxicidad de las sustancias con relación a las especies de erizos, el análisis ANOVA de dos vías demostró diferencias altamente significativas entre las distintas sustancias tóxicas de referencia $(P<0.00001)$. No obstante, el análisis ANOVA de dos vías no presentó diferencias significativas entre las tres especies de erizos (valores IC25 y IC50) para la misma sustancia tóxica de referencia $(P>0.05)$. Tampoco hubo diferencias significativas en la interacción especies-tóxicos de referencia $(P=0.05)$.

Las concentraciones de inhibición, IC25 e IC50, el número de experimentos, las desviaciones estándar y los respectivos coeficientes de variación para cada especie de erizo, correlacionadas a las distintas sustancias de referencia se describe a continuación y se muestra en las figuras 2, 3, 4 y 5. Los resultados (CI25 y CI50 \pm d.e.; sustancia tóxica de referencia, numero de tests y sus respectivos coeficientes de variación) para $A$. lixula fueron 1.71/2.48 $\pm 0.07 / 0.04 \mathrm{mg} \mathrm{L}^{-1}$ en el caso del cloruro de amonio $(n=4), \mathrm{CV} \%=4.09 / 1.6$; de 1.07/1.80 $\pm 0.11 /$ $0.06 \mathrm{mg} \mathrm{L}^{-1}$ para el cloruro de cadmio $(n=5), \mathrm{CV} \%=10.28 /$ 3.33 ; de $1.10 / 1.56 \pm 0.04 / 0.06 \mathrm{mg} \mathrm{L}^{-1}$ para el dodecilo sulfato de sodio $(n=6) \mathrm{CV} \%=3.63 / 3.84$; y de $0.03 / 0.05 \pm 0.001 /$ 0.002 para el sulfato de zinc $(n=6), \mathrm{CV} \%=6.66 / 2$ (figs. 2, 3 , 4 y 5). Para P. lividus fueron de $1.95 / 2.71 \pm 0.17 / 1.19 \mathrm{mg} \mathrm{L}^{-1}$ en el caso del cloruro de amonio $(n=4), \mathrm{CV} \%=8.71 / 7.01$; de $1.18 / 2.06 \pm 0.06 / 0.14 \mathrm{mg} \mathrm{L}^{-1}$ para el cloruro de cadmio $(n=3)$, $\mathrm{CV} \%=5.08 / 6.79$; de 1.01/1.49 $\pm 0.04 / 0.04 \mathrm{mg} \mathrm{L}^{-1}$ para el dodecilo sulfato de sodio $(n=6), \mathrm{CV} \%=3.96 / 2.68$; y de $0.03 /$ $0.05 \pm 0.001 / 0.001 \mathrm{mg} \mathrm{L}^{-1}$ para el sulfato de zinc $(n=6)$, $\mathrm{CV} \%=3,33 / 2$ (figs. 2, 3, 4 y 5). Para $S$. granularis fueron de $1.87 / 2.24 \pm 0.06 / 0.04 \mathrm{mg} \mathrm{L}^{-1}$ en el caso del cloruro de amonio $(n=3), \mathrm{CV} \%=3.20 / 1.78$; de 1.87/2.24 $\pm 0.06 / 0.04 \mathrm{mg} \mathrm{L}^{-1}$ para el cloruro de cadmio $(n=3), \mathrm{CV} \%=3.21 / 1.78$; de 1.06/1.65 \pm $0.06 / 0.04 \mathrm{mg} \mathrm{L}^{-1}$ para el dodecilo sulfato de sodio $(n=5)$, $\mathrm{CV} \%=5.66 / 2.42$; y de $0.03 / 0.05 \pm 0.001 / 0.001 \mathrm{mg} \mathrm{L}^{-1}$ para el sulfato de zinc $(n=5), \mathrm{CV} \%=3.33 / 2$ (figs. $2,3,4$ y 5 ). De 


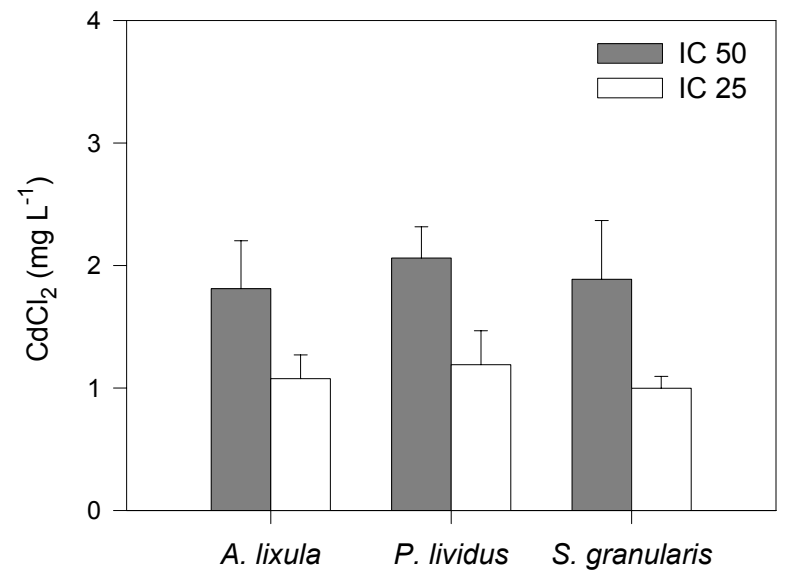

Figure 3. Reference toxicant results (IC25/50 \pm standard deviation) for cadmium chloride $\left(\mathrm{CdCl}_{2}\right)$ with sea urchins $A$. lixula, $P$. lividus and $S$. granularis.

Figura 3. Resultados de los tests de sensibilidad (IC25/50 \pm desviación estándar) con los erizos de mar $A$. lixula, $P$. lividus y $S$. granularis, frente al cloruro de cadmio $\left(\mathrm{CdCl}_{2}\right)$ como sustancia tóxica de referencia.

\section{Discussion}

Amphipods have been routinely used to evaluate toxicity because of their sensitivity to many contaminants, short generation time, ease of culture in the laboratory, tolerance to a wide range of sediment physico-chemical characteristics, and because they live in direct contact with the liquid-solid interface. The USA and Canada have recognized toxicity guidelines for sediment quality assessment. Although several standard methods have been developed for assessing the toxicity of contaminants using amphipod species from the Atlantic and Pacific coasts, no such tests have been reported for use in Europe, more specifically in the Mediterranean Sea. The results of the present study demonstrate that the amphipod $G$. aequicauda and M. gryllotalpa are suitable for toxicity determinations in the Mediterranean Sea. The reference toxicants had an effect on sea urchins similar to that observed in amphipods, although sea urchins showed greater sensitivity in all the experiments. The sea urchin tests were more effective in other ways, too; for example, they responded faster and at a lower cost, they take up less space and may be useful for low to moderate toxicity testing. Sea urchin embryos are ideal for the development of a quick bioassay system for pollutants in the marine environment (Lee, 1984). The effect of reference toxicants on the Mediterranean amphipod and sea urchin species used was similar to that recorded for species found in the bibliography (Kobayashi, 1980 ; 1984; Nacci, 1986; U.S. EPA, 1994; ASTM, 1997; Andrew, 1999). The sediment quality assessment generally involves an evaluation of solid-phase sediments, although pore water is also important, because it represents a major exposure route for benthic organisms (Whiteman et al., 1996; Carr et al., 1989; Adams et al., 1985) and substantially influences the bioavailability of contaminants (Carr et al., 1996, Ankley et al., 1994; Di Toro et al., 1991; Carr et al. 2001). The use of water column organisms such as

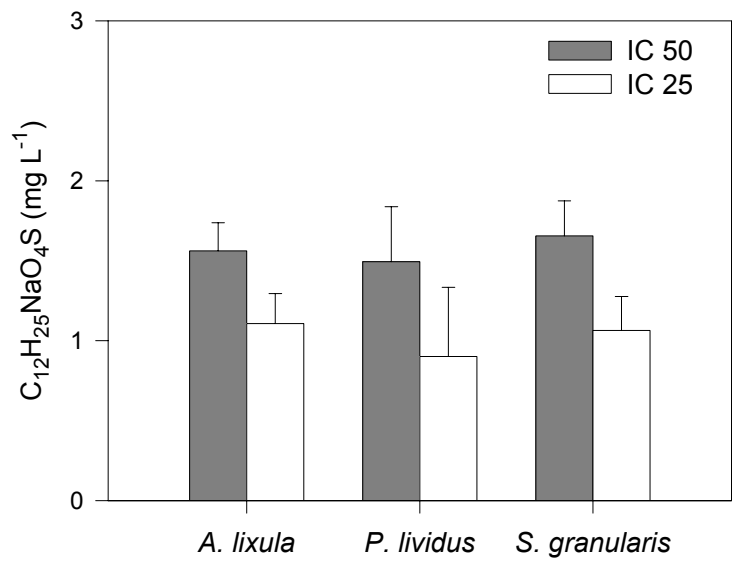

Figure 4. Reference toxicant results (IC25/50 \pm standard deviation) for sodium dodecyl-sulfate $\left(\mathrm{C}_{12} \mathrm{H}_{25} \mathrm{NaSO}_{4}\right)$ with sea urchins $A$. lixula, $P$. lividus and S. granularis.

Figura 4. Resultados de los tests de sensibilidad (IC25/50 \pm desviación estándar) con los erizos de mar $A$ lixula, $P$ lividus y $S$ granularis, frente al dodecilo sulfato de sodio $\left(\mathrm{C}_{12} \mathrm{H}_{25} \mathrm{NaSO}_{4}\right)$ como sustancia tóxica de referencia.



Figure 5. Reference toxicant results (IC25/50 \pm standard deviation) for zinc sulfate $\left(\mathrm{ZnSO}_{4}\right)$ with sea urchins $A$. lixula, $\mathrm{Pa}$. lividus and $\mathrm{S}$. granularis.

Figura 5. Resultados de los tests de sensibilidad ( $\mathrm{Cl} 25 / 50 \pm$ desviación estándar) con los erizos de mar $A$. lixula, $P$. lividus y $S$. granularis, frente al sulfato de zinc $\left(\mathrm{ZnSO}_{4}\right)$ como sustancia tóxica de referencia.

entre todas las sustancias estudiadas, el sulfato de zinc fue la más tóxica para las tres especies de erizos. Las respuestas de las larvas de las tres especies de erizos al dodecilo sulfato de sodio fueron muy uniformes, presentando una pequeña variabilidad en los datos. La sensibilidad de estas especies mediterráneas es similar a la de otras especies de erizos de mar encontradas en la bibliografía (Kobayashi, 1980; 1984; Nacci, 1986). Los coeficientes de variación (CV\%) entre los resultados obtenidos para las tres especies de erizos de mar, en relación a las cuatro sustancias tóxicas de referencia, presentaron una buena precisión. Los parámetros de calidad del agua (temperatura, oxígeno disuelto, salinidad y $\mathrm{pH}$ ) se mantuvieron constantes durante la realización de los experimentos y dentro de límites aceptables. 
sea urchin larvae for pore water toxicity has been recommended for understanding potential biological impact (Adams et al., 1985). A comparison of the sensitivity to chemical substances of marine organisms representative of the water column and benthonic species (epibenthonic and burrowing) showed that the sensitivity of planktonic species is similar to that of epibenthic species and higher than that of burrowing species (Zarba, 1992; Nagell et al., 1974). Reference toxicants such as cadmium $\left(\mathrm{CdCl}_{2}\right)$, copper $\left(\mathrm{CuSO}_{4}\right)$ and sodium dodecyl-sulfate $\left(\mathrm{C}_{12} \mathrm{H}_{25} \mathrm{NaSO}_{4}\right)$ have been recommendable (U.S. EPA, 1994), although no single reference toxicant showed has been used to measure the condition of test organisms in respect to another toxicant with a different way of action (Lee, 1980). However, it may be unrealistic to use more than one or two reference toxicants routinely (U.S. EPA, 1994). Reish (1988) reported the relative toxicity of six metals (arsenic, cadmium, chromium, copper, mercury, and zinc) towards crustaceans, polychaetes, pelecypods and fish and concluded that none of these species or groups of test organisms was more sensitive to all of the metals.

We have reported the sensitivity of the amphipods $G$. aequicauda and M. gryllotalpa, and the sea urchins, A. lixula, $P$. lividus and $S$. granularis, to common reference toxicants. In conclusion, the methodology developed using these amphipods and sea urchins is useful for the evaluation and characterization of marine contamination in Mediterranean ecosystems.

\section{Acknowledgements}

This study was funded by a grant from MUTIS-AECI (Agencia Española de Cooperación Internacional) of the Spanish Government and by the project ACU00-012-C2-2 of the Spanish Commission of Science and Technology (CICYT).

\section{References}

Adams, W.J., Kimerle, R.A. and Mosher, R.G. (1985). Aquatic safety assessment of chemicals sorbed to sediments. In: R.D. Cardwell, R. Purdy and R.C. Bahner (eds.), Aquatic toxicology and hazard assessment: Seventh symposium. Philadelphia (PA): ASTM.STP 854, pp. 429-453.

Andrew, K., Leight, R.F. and Van, D. (1999). Acute toxicity of the insecticides endosulfan, chlorpyrifos, and malathion to the epibenthic estuarine amphipod Gammarus palustris (Bousfield). Envirom. Toxicol. Chem., 18: 958-964.

Ankley, G.T., Tomas, N.A., Di Toro, D.M. and others. (1994). Assessing potential bioavailability of metals in sediments: A proposed approach. Environ. Manage., 18: 331-337.

ASTM (1990). Proposed standard guide for conducting toxicity tests with sperm and eggs of sea urchins and other echinoids. Amer. Soc. Testing and Materials, Philadelphia, PA. 61 pp.

American Public Health Association, American Water Works Association, and Water Pollution Control Federation. (1995). Standard Methods, 18th ed. American Public Health Association, Washington, DC.

American Society for Testing and Materials. (1997). Standard guide for conducting 10-day static sediment toxicity tests with marine

\section{Discusión}

Los anfípodos han sido utilizados rutinariamente en la evaluación de la toxicidad debido a su gran sensibilidad a un buen número de contaminantes, por su corto período de vida, por la facilidad de su cultivo en laboratorio, por su tolerancia a un amplio rango de características fisico-químicas en el sedimento y, además, por vivir en contacto directo con la interfase sedimento-agua. En los Estados Unidos y Canadá se han creado protocolos de toxicidad para valorar la calidad de las aguas y sedimentos marinos. A pesar de los numerosos métodos estándar que han sido desarrollados para valorar la toxicidad de los contaminantes usando especies de anfípodos de las costas del Atlántico y el Pacífico, no se ha descrito ningún protocolo estándar de características similares para su uso en Europa y, más concretamente, con especies mediterráneas. El resultado de este estudio demuestra que los anfípodos $G$. aequicauda y M. gryllotalpa son adecuados para la determinación de la toxicidad en el Mediterráneo. Los experimentos con las sustancias tóxicas de referencia demostraron un efecto similar para las especies de anfípodos y erizos, sin embargo, los erizos de mar exhibieron una mayor sensibilidad a todas las sustancias tóxicas de referencia. Los tests con erizos demostraron, además, resultados más efectivos en otros aspectos como: menores coeficientes de variación, respuestas más rápidas, menor coste, requieren menos espacio y resultan más efectivos en casos de baja a moderada toxicidad. Los embriones de erizos de mar son ideales como organismos tests y pueden detectar rápidamente los efectos de los contaminantes en el medio marino (Lee, 1984). Los efectos de las sustancias tóxicas de referencia en las dos especies de anfípodos mediterráneos y en las tres especies de erizos de mar usados fueron comparables a los descritos en la bibliografía (Kobayashi, 1980; 1984; Nacci, 1986; U.S. EPA, 1994; ASTM, 1997; Andrew, 1999). La valoración de la calidad del sedimento generalmente requiere la evaluación de la toxicidad en la fase sólida, aunque el agua intersticial también es determinante porque representa una vía importante de exposición para los organismos bentónicos (Whiteman et al., 1996; Carr et al., 1989; Adams et al., 1985) e influencia de manera considerable la biodisponibilidad de los contaminantes (Carr et al., 1996, Ankley et al., 1994; Di Toro et al., 1991; Carr et al., 2001). La evaluación de la toxicidad del agua intersticial por medio de la utilización de animales que habitan la columna de agua como las larvas de erizos de mar ha sido recomendada para la detección del impacto biológico potencial (Adams et al., 1985). Una comparación de la sensibilidad a las sustancias químicas entre organismos marinos representativos de la columna de agua y bentónicos (epibentónicos y excavadores), mostró que la sensibilidad de las especies planctónicas es similar a la de las epibentónicas y mayor que la de las especies excavadoras (Zarba, 1992; Nagell et al., 1974). Las sustancias tóxicas de referencia como cadmio $\left(\mathrm{CdCl}_{2}\right)$, cobre $\left(\mathrm{CuSO}_{4}\right)$ y dodecilo sulfato de sodio $\left(\mathrm{C}_{12} \mathrm{H}_{25} \mathrm{NaSO}_{4}\right)$ son recomendadas (U.S. EPA, 1994), no sólo como simples tóxicos de referencia, sino que pueden también 
and estuarine amphipods. E1367-92. Annual Book of ASTM Standards, Vol. 11.05. Philadelphia, PA, pp. 731-756.

Bryn, M.P., Brian, S.A. and Hunt, J.W. (1998). Spatial and temporal variation in results of purple urchin (Strongylocentrotus purpuratus) toxicity tests with Zinc. Environ. Toxicol. Chem., 17: 453-459.

Buchanan, J.B. (1984). Sediment analysis. In: N.A. Holme and A.D. Mcintyre (eds); Methods for the Study of Marine Benthos, Blackwell Scientific Publications. pp. 41-65.

Carr, R.S., Williams, J.W. and Fragata, C.T.B. (1989). Development and evaluation of a novel marine sediment porewater toxicity test with the polychaete Dinophilus gyrociliatus. Environ. Toxicol. and Chem., 8: 533-543.

Carr, R.S., Chapman, D.C., Presley, B.J. and others. (1996). Sediment porewater toxicity assessment studies in the vicinity of offshore oil and gas production platforms in the Gulf of Mexico. Can. J. Fish Aquat. Sci., 53: 2618-2628.

Carr, R.S., Long, E.R., Windom, H.L. and others. (1996). Sediment quality assessment studies of Tampa Bay, Florida. Environ. Toxicol. Chem., 15: 1218-1231.

Carr, R.S., Nipper, M., Adams, W.J. and others. (2001). Summary of a SETAC technical workshop: Porewater toxicity testing: Biological, chemical and ecological considerations with a review of methods and applications, and recommendations for future areas of research. Pensacola, FL. Environ. Toxicol. Chem., 38 pp.

Chapman, G.A. (1991). Sea urchin sperm test protocol for interlaboratory comparison, U.S. EPA. Branch, Newport. OR.

Chapman, P.M. (1996). Presentation and interpretation of sediment quality triad data. Ecotoxicology, 5: 327-339.

Cesar, A., Marín, L., Vita, R., and others. (2000). Test de toxicidad con sedimento marino en la costa Mediterránea empleando anfípodos: Gammarus aequicauda y Microdeutopus gryllotalpa. In: G. Espíndola, R. Paschoal, O. Rocha, C. Bohrer and L. Neto (eds.), Ecotoxicologia: Perspectivas para o Século XXI, São Carlos, RiMa, pp.17-27.

CETESB. (1999). Método de ensaio: Água do mar - Teste de toxicidade crônica de curta duração com Lytechinus variegatus, Lamark, 1816 (Echinodermata: Echinoidea). L5.250. Cia. de Tecnologia de Saneamento Ambiental do Estado de São Paulo, Brasil. 22 pp.

Del-Valls, T.A., Forja, J.M. and Gómez-Parra, A. (1998). Integrative assessment of sediment quality in two littoral ecosystems from the Gulf of Cádiz, Spain. Environ. Toxicol. Chem., 17: 1073-1084.

Di Toro, D.M., Zarba, C.S., Hansen, D.J. and others. (1991). Technical basis for establishing sediment quality criteria for nonionic organic chemicals using equilibrium partitioning. Environ. Toxicol. Chem., 10: 1541-1583.

Environment Canada. (1992). Biological test method: Fertilization assay using echinoids (sea urchins and sand dollars), amended November 1997. EPS 1/RM/27. North Vancouver, BC, 97 pp.

Gannon, J.E. and Beeton, A.M. (1971). Procedures for determining the effects of dredge sediments on biota - benthos viability and sediment selectivity tests. J. Wat. Pollut. Control Fed., 43: 392389.

Hamilton, M.A., Russo, R.C. and Thurston, R.V. (1977). Trimmed Spearman-Karber method for estimating median lethal concentrations in toxicological bioassays. Envir. Sci. Technol., 11: 714-719; correction 12: 417, 1978. caracterizar las condiciones de los organismos tests empleados en los experimentos (Lee, 1980). Además, puede ser complicado usar más de una o dos sustancias tóxicas de referencia rutinariamente (U.S. EPA, 1994). Reish (1988) describió la toxicidad de seis metales (arsénico, cadmio, cromo, cobre, mercurio y zinc) en crustáceos, poliquetos, pelecípodos y peces, concluyendo que ninguna especie o grupo poseía mayor sensibilidad a cualquiera de los metales citados.

Hemos demostrado la sensibilidad de los anfípodos $G$. aequicauda y $M$. gryllotalpa y los erizos de mar $A$. lixula, $P$. lividus y $S$. granularis a las distintas sustancias tóxicas de referencia utilizadas en este estudio. En conclusión, la metodología desarrollada usando estos anfípodos y erizos de mar demostró una gran aplicabilidad en la evaluación y caracterización de la contaminación marina en ecosistemas mediterráneos.

\section{Agradecimientos}

Este estudio fue subvencionado por el gobierno español a través de la Agencia Española de Cooperación Internacional (Beca-MUTIS) y por el proyecto ACU00-012-C2-2 de la Comisión Española de Ciencia y Tecnología (CICYT).

Traducción al español por los autores.

Hunt, J.W., Anderson, B.S., Phillips, B.M. and others. (2001a). A large-scale categorization of sites in San Francisco Bay, USA, based on the sediment quality triad, toxicity identification evaluations, and gradient studies. Environ. Toxicol. Chem., 20: 1252-1265.

Hunt, J.W., Anderson, B.S., Phillips, B.M. and others. (2001b). Evaluation and use of sediment toxicity reference sites for statistical comparisons in regional assessments. Environ. Toxicol. Chem., 20: 1266-1275.

Kobayashi, N. (1980). Comparative sensitivity of various developmental stages of sea urchins to some chemicals, Marine Biology, 58: 163-171.

Kobayashi, N. (1984). Marine ecotoxicological testing in echinoderms. In: G. Persoone., E. Jaspers and C. Claus (eds.), Ecotoxicological Testing for the Marine Environment. Bredene, Belgium. pp. 341-381.

Lee, D.R. (1980). Reference toxicants in quality control of aquatic biossay. In: A.L. Buikema, and J. Cairns Jr. (eds.), Aquatic Invertebrate Bioassays. ASTM, STP, 715, Philadelphia, PA. pp. 188-199.

Lee, H.H. (1984). Effects of metals on sea urchin development: A rapid bioassay. Mar. Pol. Bul., 15(1): 18-21.

Martín, A.O., Tocino, L.S., González, S.L. and Martín, J.F.V. (1999). Guía Submarina de Invertebrados no Artrópodos. Comares, Granada, 401 pp.

Nacci, D.E., Jackim, E. and Walsh, R. (1986). Comparative evaluation of three marine toxicity tests: Sea urchin embryo growth test, sea urchin sperm cell toxicity test and microtox. Environ. Toxicol. Chem., 5: 521-526.

Nagell, B., Notini, M. and Grahn, O. (1974). Toxicity of four oil dispersants to some animals from the Baltic Sea. Marine Biology, 28: $237-243$. 
Nipper, M.G., Prósperi, V.A. and Zamboni, A.J. (1993). Toxicity testing with coastal species of southeastern Brazil. Echinoderm Sperm and Embryos. Environ. Contam. Toxicol., 50: 646-652.

Riedl, R. (1986). Fauna und Flora des Mittelmeres. Verlarg Paul Parey, Hamburg-Berlin, 848 pp.

Reish, D.J. (1988). The use of toxicity testing in marine environmental research. In: D.F. Soule and G.S. Kleppel (eds.), Marine Organisms as Indicators. Springer-Verlag. NY, pp. 213245.

Ruffo, S. (1982). The Amphipoda of the Mediterranean. Mémoires de I'Institut Océanographique, Monaco, (13): $360 \mathrm{pp}$.

Swartz, R.C, DeBen, W.A., Sercu, K.A.. and Lamberson, J.O. (1982). Sediment toxicity and the distribution of the amphipods in Commencement Bay, Washington, USA. Mar. Pol. Bul., 13: 359364.

U.S. Environmental Protection Agency. (1988). Short-term methods for estimating the chronic toxicity of effluents and receiving waters to marine and estuarine organisms. EPA-600/4-87/028, Cincinnati, $\mathrm{OH}$.
U.S. Environmental Protection Agency. (1994). Methods for assessing the toxicity of sediment-associated contaminants with estuarine and marine amphipods. EPA/600/-94/025, Narragansett, Rhode Island 02882.

U.S. Environmental Protection Agency. (1995). Short-term methods for estimating the chronic toxicity of effluents and receiving waters to west coast marine and estuarine organisms. EPA/600/ R95-136. Cincinnati, Ohio.

U.S. Environmental Protection Agency. (1993). A Linear Interpolation Method for Sublethal Toxicity: The Inhibition Concentration (ICp) Approach. Duluth, MN 55804.

Zarba, C. (1992). Equilibrium partitioning approach. In: U.S. EPA (ed.), Sediment Classification Methods Compendium. 6:6-1-6-10. Washington, D.C.: Environmental Protection Agency.

Whiteman, F.M., Ankley, G.T., Kahl, M.D. and others. (1996). Evaluation of interstitial water as route of exposure for ammonia in sediment tests with benthic macroinvertebrates. Environ. Toxicol. Chem., 15: 794-801. 